\title{
Zkoumání povahy žákovských promluv ve výuce anglického jazyka ${ }^{1}$
}

\author{
Analysing the nature of pupils' ${ }^{6}$ utterances in English lessons
}

\author{
Veronika Najvarová, Světlana Hanušová, Martin Adam, Petr Najvar
}

\begin{abstract}
Abstrakt: Příspěvek představuje metodologii a vybrané výsledky výzkumu promluv učitele a zejména žáků ve výuce anglického jazyka na druhém stupni základní školy. Budou představeny zejména kategoriální systémy vytvořené pro potřeby prezentovaného výzkumu, zaměřené na zjištění proporcí využívání mateřského a cílového jazyka a na postižení povahy anglických promluv žáků $\mathrm{v}$ reálné výuce. $\mathrm{V}$ teoretické rovině se výzkum opírá o koncept komunikačního př́stupu ve výuce cizích jazyků. Hlavní metodou sběru dat bylo zprostředkované pozorování (videostudie). Analyzováno bylo 79 vyučovacích hodin, jednotkou analýzy byl 10vteřinový interval. Z výsledků vyplývá, že existují značné rozdíly $\mathrm{v}$ tom, jakým způsobem je výuka organizována jednotlivými učiteli a jaké př́ležitosti $\mathrm{k}$ mluvení žákům výuka nabízí.
\end{abstract}

Klíčová slova: videostudie, kategoriální systém, výzkum výuky, příležitosti k mluvení, interakce, komunikace

\begin{abstract}
In the paper the authors introduce the methodology and selected findings of a research project that focused on teachers' and pupils' utterances during English instruction as it was realized on lower-secondary level in the Czech Republic. The authors introduce systems of categories that were developed to be used to discover the proportions between the target language and the mother tongue and to capture and describe the nature of pupils' utterances during instruction. The research builds on the concept of the communicative approach in the teaching and learning of English. The main research method was videomediated observation - video study and transcript analysis. We analysed 79 transcripts; the analytical unit was a 10 -second interval. The findings indicate that there are vast differences in classroom organisation and in opportunities to talk that are offered to pupils.
\end{abstract}

Keywords: video study, systems of categories, research on instruction, opportunities to talk, interaction, communication

\section{1 Úvod}

Vysoká poptávka po komunikačních dovednostech v anglickém jazyce, který je v současné době společným dorozumívacím prostředkem (lingua franca) nejen sjednocené Evropy, ale i globalizujícího se světa, vedla v posledních desetiletích ke vzrůstajícímu zájmu o proces osvojování cizího jazyka a o rozvoj komunikační metodologie, která by se měla stát základem efektivního vyučování cizímu jazyku. Tento trend se projevuje i v českých školách př́íklonem

\footnotetext{
${ }^{1}$ Př́ispěvek vznikl za podpory projektu LC 06046 Centrum výzkumu školního vzdělávání poskytnutého Ministerstvem školství, mládeže a tělovýchovy České republiky.
} 
ke komunikačnímu př́ístupu, alespoň pokud jde o strategie a principy deklarované v současných kurikulárních dokumentech. Otázkou, která inspirovala výzkumnou studii, jejíž metodologii nastiňuje tento př́spěvek, zůstává, jakým zpo̊sobem posoudit, zda je komunikační metodologie implementována do každodenní praxe cizojazyčné výuky na základních školách.

\section{Teoretická východiska}

V této výzkumné studii se opíráme o tři teoretická východiska - komunikativní př́stup, analýzu diskurzu a prŕležitosti k učení (mluvení) žáků.

V rámci komunikačního př́stupu se otvírá širší perspektiva pohledu na jazyk, který už není chápán jen skrze výčet jednotlivých struktur (gramatika, slovní zásoba), ale zejména ve smyslu funkcí, které jazyk plní. V procesu vyučování je třeba rozvíjet strategie přiřazování jazykových struktur jejich komunikačním funkcím $v$ reálných situacích a reálném čase (Littlewood, 1994). Pro implementaci výše uvedených principů do školního vyučování nestačí tedy pouze realizovat průpravná cvičení a objasňovat jednotlivé jazykové struktury, což bylo typické pro tradiční př́stupy, ale je třeba se důsledně věnovat i vytváření komunikačních př́ležitostí. Základním východiskem komunikačního př́stupu je chápání komunikace nejen jako cíle, ale i cesty k cíli. Žák se učí jazyku jeho používáním, autentickou komunikací v cílovém jazyce. Rámcový vzdělávací program pro základní vzdělávání (2010) se k tomuto pojetí komunikačního př́stupu $\mathrm{k}$ cizojazyčné výuce explicitně hlásí. Cílem výuky cizího jazyka je dosažení výstupů $\mathrm{z}$ učení formulovaných jako komponenty cizojazyčné komunikativní kompetence žáka na úrovni A2.

Diskurz školní tř́idy a jeho analýza zaujímají významné místo jak v aplikované jazykovědě, tak v didaktice. Zatímco někteří badatelé vnímají tento diskurz ryze lingvisticky, jiní k němu přistupují jako k jevu etnografickému, sociologickému či psychologickému (např. Christie, 2002, s. 1). Strukturovaná vyučovací hodina vnímána jako jednotka diskurzu školní třídy (Hatch \& Long, 1980; srov. Betáková, 2010). V souladu s tvrzením Johnsona (1995, s. 3) se nám jazyk jeví jako základní nástroj učitele cizího jazyka; představuje totiž médium, skrze které učitel učí, a žáci ukazují, čemu se naučili. Podobně i Betáková (2010, s. 56) vidí komunikaci ve třídě jako primární aspekt výuky. Domnívá se totiž, že učitel vládne penzem znalostí a schopností, které má předat svým žákům; v rámci diskurzu školní třídy učitel vyučovaný jazyk zná, žáci nikoliv. Zároveň však připouští, že role učitele není jen transmisivní, nýbrž spíše konstruující - v komunikačním pojetí výuky mají žáci své prekoncepty, se kterými může učitel pracovat.

V této studii analyzujeme výuku skrze koncept př́iležitostí k učení, které umožňují analyzovat výuku jako komplexní jev (Janík, Najvar, 2008). Mohou být operacionalizovány různými způsoby (viz např. Šebestová, 2009), nejčastěji se jedná o čas (allocated time), který mají žáci učitelem vyměřený k práci na zadaném úkolu. Při kvalitativním pohledu na př́ležitosti k učení mohou být utvářeny nabídkou vhodně strukturovaných aktivit, které umožňují sociální interakci. V sociální interakci jsou žáci vybízeni k vytváření promluv v cílovém jazyce.

\section{Cíle př́íspěvku}

Cílem tohoto příspěvku je představit kategoriální systémy využité v analýzách realizovaných v rámci projektu CPV videostudie anglického jazyka, jejichž výsledky budou publikovány na jiném místě (Hanušová et al., v tisku). 


\section{Kontext analýzy}

Prezentované kategoriální systémy byly využity $\mathrm{v}$ analýzách realizovaných $\mathrm{v}$ rámci projektu CPV videostudie anglického jazyka (Najvar et al., 2008), jenž se zaměřoval na reálnou výuku anglického jazyka na druhém stupni základních škol. Projekt CPV videostudie anglického jazyka zachytil pro analýzy výuku anglického jazyka na 2. stupni základních škol ve školním roce 2006/07. Výzkumný vzorek tvořilo 79 transkriptů videozáznamů vyučovacích hodin. Analytickou jednotku ve většině analýz tvořil 10sekundový interval výuky, celkem bylo analyzováno 20833 takových intervalü² .

Pro potřeby analýz rozlišujeme dvě roviny komunikace, která se ve tř́idě odehrává. Tzv. veřejná komunikace je komunikace učitele a celé tř́́dy či většiny žáků, tzv. soukromá komunikace probíhá mezi učitelem a jedním či několika málo žáky nebo v rámci dvojice či skupiny žáků. Předmětem analýz $\mathrm{v}$ prezentovaných sondách byla výhradně veřejná komunikace. Intervaly, v nichž probíhala soukromá komunikace, sytily zvláštní kategorii (skupinová práce), dále analyzovat soukromou komunikaci však nebylo z technických důvodů možné.

\subsection{Shoda mezi kódovateli}

Pro analýzu žákovských promluv v anglickém jazyce byly vytvořeny dva vlastní kategoriální systémy: Jazyk výuky a Povaha žákovských promluv. Kódování transkriptů s využitím kategoriálního systému Jazyk ve výuce bylo zajišt'ováno jednou osobou, vzhledem k tomu, že uvedený kategoriální systém je nízko-inferentní. Pokud nebylo zřejmé, do které kategorie interval kódovat, vycházelo se z počtu slov v analyzované jednotce. Kódování transkriptů $\mathrm{s}$ pomocí kategoriálního systému Povaha žákovských promluv bylo zajišs'ováno pěti kódovateli. Ve snaze dosáhnout přijatelné míry objektivnosti pozorování byla opakovaně zjišt'ována míra shody mezi kódovateli. Byla ověřována skrze míru přímé shody a koeficient Cohen's Kappa. Kategoriální systém Povaha žákovských promluv je vysokoinferentním kategoriálním systémem, který vznikal ve čtyřech fázích:

0. Př́prava kategoriálního systému (13 hodin) - byly analyzovány transkripty hodin a vytvářeny první verze kategoriálního systému.

1. $10 \%$ vzorku ( 8 hodin) - dle vytvořeného katgoriálního systému bylo nakódováno 8 hodin. Byla měřena míra přímé shody mezi 5 kódovateli $(>85)$ a Cohen's Kappa mezi 5 kódovateli $(>70)$. Byl revidován a upraven kategoriální systém podle výsledků kódování. Míru př́mé shody a Cohen's Kappa uvádíme v tabulce 1 a 2.

2. $25 \%$ vzorku ( 20 hodin) - každý kódovatel analyzoval nových 8 transkriptů (každé 2 transkripty byly shodné pro 2 kódovatele). Zjištěné problémy byly řešeny shodou mezi všemi kódovateli, kategoriální systém byl dále zpřesňován.

3. $100 \%$ vzorku (79 hodin) - již nebylo třeba kategoriální systém upravovat, bylo možné dle něj nakódovat i problémové situace. Kódování již probíhalo individuálně.

\footnotetext{
${ }^{2}$ Podrobněji o výběru vzorku a jeho charakteristikách viz Najvar et al. 2008).
} 
Tabulka 1

Mira prrímé shody mezi 5 kódovateli

\begin{tabular}{ccccccccccc}
\hline & $1+2$ & $1+3$ & $1+4$ & $1+5$ & $2+3$ & $2+4$ & $2+5$ & $3+4$ & $3+5$ & $4+5$ \\
\cline { 2 - 9 } B4 & 89,6 & 95,5 & 88,8 & 94 & 89,6 & 83,3 & 88,5 & 87,4 & 92,2 & 88,8 \\
E4 & 87 & 94,7 & 89,9 & 83,5 & 88 & 82,5 & 82 & 91,5 & 82,1 & 85,5 \\
O3 & 88,8 & 78 & 87,4 & 83,5 & 87,8 & 89 & 85,6 & 77,7 & 74,1 & 83 \\
H3 & 91,4 & 95,7 & 88,3 & 88,3 & 87,9 & 84,4 & 84 & 87,9 & 89,1 & 84,4 \\
P2 & 85,9 & 84,7 & 83,5 & 89,8 & 90,6 & 91,79 & 84,7 & 93,8 & 89,4 & 86,3 \\
W1 & 85,3 & 85,8 & 82,3 & 88,8 & 81,8 & 85,6 & 85,2 & 81,2 & 85 & 81,9 \\
A1 & 92,8 & 87,5 & 92,5 & 92,1 & 85,7 & 88,6 & 87,5 & 83,2 & 89,7 & 86,8 \\
D3 & 93,8 & 93,8 & 94,8 & 94,8 & 81 & 94,8 & 91,9 & 94,8 & 91,9 & 94,1 \\
\hline
\end{tabular}

Tabulka 2

Hodnota Cohen's Kappa mezi 5 kódovateli

\begin{tabular}{ccccccccccc}
\hline & $1+2$ & $1+3$ & $1+4$ & $1+5$ & $2+3$ & $2+4$ & $2+5$ & $3+4$ & $3+5$ & $4+5$ \\
\cline { 2 - 9 } B4 & 0,76 & 0,91 & 0,774 & 0,866 & 0,76 & 0,643 & 0,739 & 0,748 & 0,829 & 0,77 \\
E4 & 0,663 & 0,85 & 0,733 & 0,593 & 0,692 & 0,572 & 0,601 & 0,788 & 0,548 & 0,644 \\
O3 & 0,737 & 0,787 & 0,757 & 0,709 & 0,753 & 0,747 & 0,694 & 0,791 & 0,742 & 0,702 \\
H3 & 0,881 & 0,944 & 0,848 & 0,849 & 0,834 & 0,79 & 0,786 & 0,843 & 0,859 & 0,801 \\
P2 & 0,885 & 0,882 & 0,867 & 0,918 & 0,918 & 0,93 & 0,876 & 0,946 & 0,913 & 0,889 \\
W1 & 0,807 & 0,822 & 0,848 & 0,849 & 0,721 & 0,834 & 0,768 & 0,781 & 0,847 & 0,814 \\
A1 & 0,74 & 0,795 & 0,726 & 0,756 & 0,628 & 0,688 & 0,72 & 0,695 & 0,582 & 0,621 \\
D3 & 0,914 & 0,84 & 0,856 & 0,767 & 0,712 & 0,682 & 0,734 & 0,81 & 0,832 & 0,867 \\
\hline
\end{tabular}

\section{Kategoriální systémy}

Pro analýzu jazyka ve výuce angličtiny na 2 . stupni ZŠ byly vytvořeny dva kategoriální systémy, které představujeme níže.

\subsection{Kategoriální systém Jazyk výuky}

Kategoriální systém Jazyk výuky umožňuje analyzovat, v jakém jazyce je výuka realizována zda v mateřském nebo cílovém jazyce (tabulka 3). Kategoriální systém obsahuje 7 kategorí́. Stěžejních 6 kategorií postihuje jazyk, kterým se ve výuce mluví (kategorie česky, mix s prevahou $\check{C}$ j, mix 50 na 50, mix s převahou Aj, anglicky, skupinová práce). Poslední kategorie ticho/psani umožňuje zaznamenat intervaly, ve kterých neprobíhá veřejná komunikace nebo se ve výuce nemluví. Byly analyzovány transkripty 79 hodin, analytickou jednotkou byl 10sekundový interval. 
Tabulka 3

Kategoriálni systém Jazyk výuky

\begin{tabular}{|c|c|c|c|}
\hline & název & popis & skupina \\
\hline 1 & česky & $\begin{array}{l}\text { V pozorovaném intervalu probíhá veřejná komunikace učitele se žáky } \\
\text { nebo mezi žáky v českém jazyce. }\end{array}$ & \multirow{2}{*}{$\frac{\oint_{2}}{\frac{\infty}{2}}$} \\
\hline 2 & mix s převahou Čj & $\begin{array}{l}\text { Do kategorie mix zařazujeme intervaly, ve kterých byl použit jak český, } \\
\text { tak i anglický jazyk, použití češtiny je ale v převaze (tj. nad } 50 \% \\
\text { použitých slov v intervalu). }\end{array}$ & \\
\hline 3 & $\operatorname{mix} 50$ na 50 & $\begin{array}{l}\text { Do kategorie mix zařazujeme intervaly, ve kterých byl použit jak český, } \\
\text { tak i anglický jazyk, přičemž nemǔžeme rozhodnout, který jazyk byl } \\
\text { použit dominantně (často rozhoduje i shodný počet slov v obou } \\
\text { jazycích). Může se jednat o situace, kdy učitel zkouší slovíčka, případně } \\
\text { ihned překládá své instrukce, do vět v jednom jazyce vkládá slova } \\
\text { z druhého jazyka. }\end{array}$ & 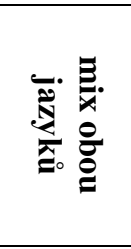 \\
\hline 4 & mix s převahou $\mathrm{Aj}$ & $\begin{array}{l}\text { Do kategorie mix s převahou Aj zařazujeme intervaly, ve kterých byl } \\
\text { použit jak anglický, tak i český jazyk, použití angličtiny je ale v převaze } \\
\text { (tj. nad } 50 \text { \% použitých slov v intervalu). Česky se může učitel } \\
\text { ujišt'ovat, že žáci rozumí, překládat slovíčka nebo části anglických vět. }\end{array}$ & \multirow{3}{*}{ 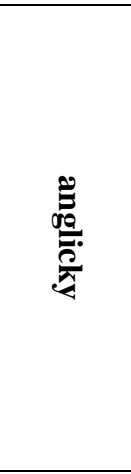 } \\
\hline 5 & anglicky & $\begin{array}{l}\text { V pozorovaném intervalu probíhá veřejná komunikace učitele se žáky } \\
\text { nebo mezi žáky v anglickém jazyce. }\end{array}$ & \\
\hline 6 & skupinová práce & $\begin{array}{l}\text { Za skupinovou práci považujeme pro tuto analýzu situace, kdy mají žáci } \\
\text { mezi sebou anglicky hovořit (např. zjišt’ování chybějící informace, } \\
\text { př́prava a nácvik rozhovoru). Podstatou zadaného úkolu může být i } \\
\text { psaní, výsledkem ale musí být souvislý text v anglickém jazyce, který } \\
\text { vznikl kooperací jednotlivých žáků. }\end{array}$ & \\
\hline 7 & ticho/psaní & $\begin{array}{l}\text { Do kategorie } 8 \text { zařazujeme intervaly, kdy neprobíhá žádná veřejná } \\
\text { komunikace. Žáci často samostatně plní zadaný úkol (např. doplňování } \\
\text { gramatických cvičení, příprava vět, tiché čtení textu, písemné zkoušení), } \\
\text { učitel často kontroluje činnost žáků, může probíhat individuální } \\
\text { komunikace učitele s určitým žákem, která ale není určena pro celou } \\
\text { třídu. }\end{array}$ & $\frac{\vec{\partial}}{\frac{\partial}{\sigma}}$ \\
\hline
\end{tabular}

\subsection{Kategoriálni systém Povaha žákovských promluv}

Cílem analýzy komunikace ve vyučování anglickému jazyku bylo popsat povahu žákovských promluv v cílovém jazyce ve veřejné komunikaci. Předmětem analýzy byly ty intervaly, v nichž se objevila výpověd' žáka v cílovém jazyce. Podle povahy výpovědi byly intervaly tříděny dle kategoriálního systému Povaha žákovských promluv, který obsahoval 17 disjunktních kategorií (tabulka 4). Intervaly obsahující více než jednu žákovskou promluvu spadaly do kategorie 16 více současné.

Jednotlivé kategorie pak byly pro větší přehlednost agregovány do čtyř základních skupin: Doslovné opakování, Řizené procvičování, Komunikační procvičování a Vice typů výpovědi současně. Do kategorie Ostatní byly zařazeny všechny promluvy učitele, promluvy žáků v českém jazyce a ostatní části výuky, ve kterých komunikace neprobíhala. 


\section{Tabulka 4}

Kategoriální systém Povaha žákovských promluv

\begin{tabular}{|c|c|c|c|}
\hline & název kategorie & popis kategorie & skupina \\
\hline 1 & $\begin{array}{l}\text { Opakování po } \\
\text { učiteli/nahrávce }\end{array}$ & $\begin{array}{l}\text { Žák doslovně opakuje slova a věty po učiteli, jiném žáku nebo } \\
\text { nahrávce (žáci mohou současně sledovat psanou verzi textu = } \\
\text { čtení během poslouchání). }\end{array}$ & \multirow{3}{*}{ 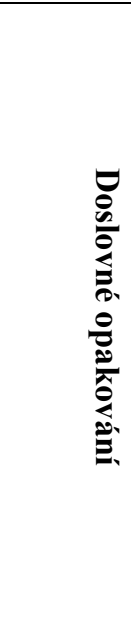 } \\
\hline 2 & Hlasité čtení & $\begin{array}{l}\text { Žák čte hlasitě text z učebnice nebo tabule. } \\
\text { Př́klad: H3 00:15:00-00:15:00 U: Tak začne číst třeba Eva, } \\
\text { tak number two. Z: You may not use the swimming pool. }\end{array}$ & \\
\hline 3 & Recitování, zpívání & $\begin{array}{l}\text { Situace, kdy žáci recitují nebo zpívají současně s přehrávačem } \\
\text { nebo zpaměti (recitují báseň, jazz chant, ale i řadu čísel, } \\
\text { abecedu), obvykle v rychlém tempu a/nebo sborově. } \\
\text { Př́klad: W1 00:04:30-00:04:50 Zopakujeme si ve všech } \\
\text { osobách. Celá třída. Everybody. I am sitting, you are sitting, he } \\
\text { is sitting, she is sitting, it is sitting, we are sitting, you are } \\
\text { sitting, they are sitting. }\end{array}$ & \\
\hline 4 & Rutinní komunikace & $\begin{array}{l}\text { Výpověd’ žáka vztahující se k rutinní komunikaci např. na } \\
\text { začátku výuky (např. zapisování do tř́ídní knihy apod.). } \\
\text { Př́iklad: Good morning, Mrs. teacher. Excuse me, I forgot my } \\
\text { homework. }\end{array}$ & \multirow{5}{*}{ 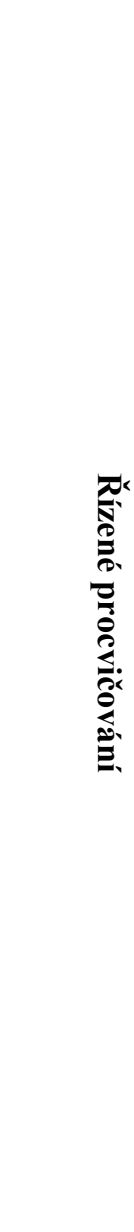 } \\
\hline 5 & $\begin{array}{l}\text { Substituční nebo } \\
\text { transformační } \\
\text { cvičení }^{3}\end{array}$ & $\begin{array}{l}\text { Žák vytváří novou větu (slovo, frázi) na základě učitelovy } \\
\text { instrukce, obrázku nebo mapy. Do této kategorie kódujeme i } \\
\text { doplňování neúplných vět, gramatická cvičení či větné } \\
\text { transformace. } \\
\text { Př́klad: Y2 00:33:50-00:34:00 U: Michale, št’astný. Z: Happy, } \\
\text { happier, the happiest. }\end{array}$ & \\
\hline 6 & Překlad slova/fráze & $\begin{array}{l}\text { Žák překládá frázi nebo slovo (doslovně, ne myšlenky nebo } \\
\text { situace), pouze z českého do anglického jazyka. } \\
\text { Př́klad: O3 00:06:40-00:06:50 U: Přijet nebo přijít, Honzo? Z: } \\
\text { Arrive. }\end{array}$ & \\
\hline 7 & $\begin{array}{l}\text { Překlad větného } \\
\text { celku/věty }\end{array}$ & $\begin{array}{l}\text { Žák překládá celou větu nebo větný celek (doslovně, ne } \\
\text { myšlenky nebo situace), pouze z českého do anglického } \\
\text { jazyka. } \\
\text { Př́klad: N1 00:11:20-00:11:30 U: Ona nehraje golf, Jano! Z: } \\
\text { She doesn't play golf. }\end{array}$ & \\
\hline 8 & $\begin{array}{l}\text { Odpověd' na } \\
\text { uzavřenou otázku }\end{array}$ & $\begin{array}{l}\text { Žák odpovídá na otázku, na kterou je pouze jedna správná } \\
\text { odpověd', učitel odpověd' zná, nebo je cílem otázky } \\
\text { procvičování jazyka. Často na začátku vyučovací hodiny } \\
\text { (rozehřátí, opakování), ale i ve fázi procvičování nebo } \\
\text { upevňování nového učiva. } \\
\text { Příklad: P2 00:00:40-00:00:50 U: How are you today? Z: I am } \\
\text { fine, thank you. U: What's your name? Z: I am Filip. }\end{array}$ & \\
\hline
\end{tabular}

\footnotetext{
3 Jednalo se zejména o gramatická cvičení (např. doplňování gramatických tvarů sloves, vytváření větných struktur, apod.).

${ }^{4}$ Vycházíme z trrídění učitelových otázek na otázky uzavřené a otevřené. Na uzavřené otázky obvykle existuje pouze jedna správná odpověd', kterou učitel předem zná, často jsou to otázky reproduktivní, s nižší kognitivní náročností. Odpověd’ na otevřené otázky není předem zřejmá a obsahuje prvek komunikativnosti (viz např. Švaříček, 2011).
} 


\begin{tabular}{|c|c|c|c|}
\hline 9 & $\begin{array}{l}\text { Oprava vlastní chyby } \\
\text { žáka }\end{array}$ & $\begin{array}{l}\text { Žák opravuje vlastní chybu, často po výzvě učitele (spontánní } \\
\text { opravy chyb nejsou zaznamenávány). } \\
\text { Př́klad: D3 00:20:00 - 00:20:10 Z: Takže, we are going play } \\
\text { tennis. U: Tak Leňo, ještě jednou a oprav se. Z: We are going } \\
\text { to play tennis. }\end{array}$ & \\
\hline 10 & $\begin{array}{l}\text { Oprava chyby jiného } \\
\text { žáka }\end{array}$ & Žák opravuje chybu jiného žáka, často na výzvu učitele. & \\
\hline 11 & $\begin{array}{l}\text { Prezentování nebo } \\
\text { předvádění výsledku } \\
\text { dř́ve připravovaného } \\
\text { úkolu }\end{array}$ & $\begin{array}{l}\text { Žáci prezentují nebo předvádějí to, co si nachystali } \\
\text { (samostatně nebo ve skupinách). } \\
\text { Př́klad: Žáci hrají scénku nebo předvádějí rozhovor, který si } \\
\text { připravili již dříve. } \\
\text { Př́íklad: R1 00:05:50-00:06:00 Z: This is story about Mickey, } \\
\text { Milli and Mut. Z: What Milli, does the USA president live in } \\
\text { New York? Z: I don't know. }\end{array}$ & \\
\hline 12 & Žákova otázka & $\begin{array}{l}\text { Žák se ptá jiného žáka nebo učitele vlastní vytvořenou } \\
\text { zjištující otázku, na kterou nezná odpověd’. } \\
\text { Př́klad: I2 00:09:50-00:10:00 U: Klárko, can you read your } \\
\text { questions, please? Z: Do you like reading books? What do you } \\
\text { do read usually? Where do you read books? }\end{array}$ & \multirow{4}{*}{ 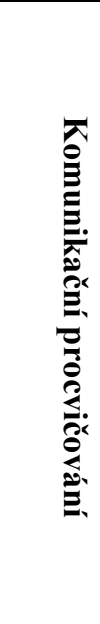 } \\
\hline 13 & $\begin{array}{l}\text { Odpověd' na } \\
\text { otevřenou otázku } \\
\text { (pravá otázka) }\end{array}$ & $\begin{array}{l}\text { Žák odpovídá na otevřenou otázku, tázající nezná předem } \\
\text { odpověd' (tzv. information gap). Učitel mǔže využít obrázek. } \\
\text { Př́klad: P2 00:05:10-00:05:20 Why do you like spring? }\end{array}$ & \\
\hline 14 & $\begin{array}{l}\text { Spontánní promluva } \\
\text { žáka }\end{array}$ & $\begin{array}{l}\text { Spontánní promluva žáka, která nebyla elicitována učitelem. } \\
\text { Př́klad: W1 00:28:50-00:29:00 Can I go to toilet, please? }\end{array}$ & \\
\hline 15 & Skupinová práce & $\begin{array}{l}\text { Situace, ve kterých žáci pracují ve dvojicích nebo skupinách. } \\
\text { Takové situace nejsou doslovně přepsány v transkriptu. }\end{array}$ & \\
\hline 16 & $\begin{array}{l}\text { Více typů jazykových } \\
\text { promluv žákủ různé } \\
\text { povahy v jednom } \\
\text { intervalu }\end{array}$ & $\begin{array}{l}\text { Situace, kdy se v jednom intervalu vyskytne více typů } \\
\text { jazykových promluv žáků v anglickém jazyce různé povahy } \\
\text { (kategorie } 1-13 \text { ) }\end{array}$ & 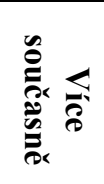 \\
\hline 17 & Ostatní & $\begin{array}{l}\text { Ostatní promluvy, které byly proneseny během výuky } \\
\text { (zahrnující promluvy učitele, promluvy žákủ v českém jazyce), } \\
\text { nebo situace, kdy žáci pracují potichu na samostatném úkolu. }\end{array}$ & 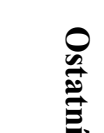 \\
\hline
\end{tabular}

\section{Závěr}

Př́spěvek představil dva kategoriální systémy, které byly využity v analýze komunikace v reálné výuce anglického jazyka na 2. stupni ZŠ v České republice. Analýzy ukázaly, že tyto kategoriální systémy umožnily postihnout více než resp. více než 98 \% výukového času, jejich šíři z hlediska postihnutí pozorovaných jevů proto považujeme za dostatečnou.

Výsledky analýz ukazují na značné rozdíly mezi učiteli z hlediska toho, jaké př́ležitosti k mluvení svým žákům nabízejí. Podrobné výsledky budou publikovány v Hanušová et al. (v tisku). 


\section{Literatura}

Betáková, L. (2010). Discourse and interaction in English language teaching. Praha: PdF UK v Praze. Hanušová, S., Najvarová, V., Najvar, P., Adam, P., \& Homolka, S. (v tisku). Analýza žákovských promluv ve výuce anglického jazyka: vybrané výsledky CPV videostudie anglického jazyka.

Hatch, E. \& Long M. H. (1980). Discourse analysis, What's that? In D. Larsen-Freeman (Ed.), Discourse analysis in second language research. Newbury House: Rowley, Massachusetts.

Christie, F. (2002). Classroom discourse analysis. London: Continuum.

Janík, T., \& Najvar, P. (2008). Videostudie ve výzkumu vyučování a učení. Orbis scholae, 2(1), 7-28.

Johnson, K. E. (1995). Understanding communication in second language classrooms. Cambridge: University Press.

Littlewood, W. (1994). Communicative language teaching. Cambridge: CUP.

Najvar, P., Najvarová, V., Soběslavská, V., Šebestová, S., Vlčková, K., \& Zerzová, J. (2008). CPV videostudie anglického jazyka: sběr dat a zamýšlené analýzy. Orbis scholae, 2(1), 73-91.

Rámcový vzdělávací program pro základní vzdělávání (2010). Praha: Výzkumný ústav pedagogický.

Šebestová, S. (2009). Př́ležitosti k rozvíjení jazykových dovedností v hodinách anglického jazyka. In T. Janík, V. Švec et al. K perspektivám školniho vzděláváni (pp. 193-208). Brno: Paido.

Švaříček, R. (2011). Funkce učitelských otázek ve výukové komunikaci na druhém stupni základních škol. Studia paedagogica, 16(1), 9-46.

\section{Kontakt}

Mgr. Veronika Najvarová, Ph.D.

Mgr. Petr Najvar, Ph.D.

Masarykova univerzita

Pedagogická fakulta, Institut výzkumu školního vzdělávání

Poříčí 7, 60300 Brno

e-mail: najvarova@gmail.com

doc. Mgr. Světlana Hanušová, Ph.D.

Mgr. Martin Adam, Ph.D.

Masarykova univerzita

Pedagogická fakulta, Katedra anglického jazyka a literatury

Poříčí 7, 60300 Brno

\section{Bibliografické údaje}

Najvarová, V., Hanušová, S., Adam, M., \& Najvar, P. (2011). Zkoumání povahy žákovských promluv ve výuce anglického jazyka. In T. Janík, P. Knecht, \& S. Šebestová (Eds.), Smíšený design v pedagogickém výzkumu: Sborník přispěvki̊ z 19. výročni konference České asociace pedagogického výzkuтu (s. 130-137). Brno: Masarykova univerzita.

Dostupné z: http://www.ped.muni.cz/capv2011/sbornikprispevku/najvarovaetal.pdf

doi: 10.5817/PdF.P210-CAPV-2012-41 